\title{
Law and Lawlessness in Early Judaism and Early Christianity
}

\author{
edited by \\ David Lincicum, Ruth Sheridan, \\ and Charles Stang
}

Mohr Siebeck

E-offprint of the author with publisher's permission. 
David Lincicum, born 1979, is the Rev. John A. O'Brien Associate Professor of Theology at the University of Notre Dame.

Ruth SHERIDAn, born 1980, is a senior research fellow at Western Sydney University affiliated with the Religion and Society Research cluster and working within the Translational Health Research Institute.

Charles M. Stang, born 1974, is Professor of Early Christian Thought and Director of the Center for the Study of World Religions at Harvard Divinity School.

ISBN 978-3-16-156708-7 / eISBN 978-3-16-156709-4

DOI 10.1628 / 978-3-16-156709-4

ISSN 0512-1604 / eISSN 2568-7476 (Wissenschaftliche Untersuchungen zum Neuen Testament)

Die Deutsche Nationalbibliothek lists this publication in the Deutsche Nationalbibliographie; detailed bibliographic data is available on the Internet at $h t t p: / / d n b . d n b . d e$.

(C) 2019 by Mohr Siebeck, Tübingen, Germany. www.mohrsiebeck.com

This book may not be reproduced, in whole or in part, in any form (beyond that permitted by copyright law) without the publisher's written permission. This applies particularly to reproductions, translations and storage and processing in electronic systems.

The book was typeset by Martin Fischer in Tübingen, printed by Gulde Druck in Tübingen on non-aging paper and bound by Buchbinderei Spinner in Ottersweier.

Printed in Germany.

E-offprint of the author with publisher's permission. 


\section{Contents}

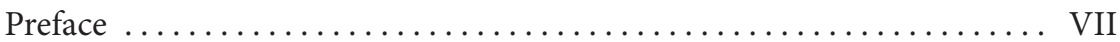

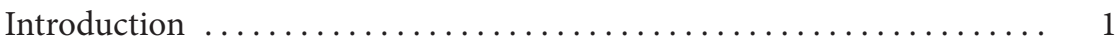

Lutz Doering

Law and Lawlessness in Texts from Qumran .................. 9

Grant MACASKILL

Law and Lawlessness in the Enoch Literature $\ldots \ldots \ldots \ldots \ldots \ldots . . \ldots 29$

Joshua D. Garroway

Paul: Within Judaism, Without Law $\ldots \ldots \ldots \ldots \ldots \ldots \ldots \ldots \ldots$

Paula Fredriksen

Origen and Augustine on Paul and the Law $\ldots \ldots \ldots \ldots \ldots \ldots \ldots . \ldots 7$

David M. Moffitt

Weak and Useless? Purity, the Mosaic Law, and Perfection in Hebrews . . 89

DAVId Lincicum

Against the Law: The Epistle of Barnabas and Torah Polemic in Early Christianity ...................................... 105

Paul F. Bradshaw

The Ancient Church Orders: Early ecclesiastical law? ............. 123

Steven D. Fraade

Rabbis on Gentile Lawlessness. Three Midrashic Moments . . . . . . . . . . 135

Michal Bar-Asher Siegal

Law Corpora Compared: Early Collections of Monastic Rules and Rabbinic Literature ............................. 157

E-offprint of the author with publisher's permission. 
Christopher Rowland

"By an immediate revelation ... by the voice of his own spirit to my soul":

A perspective from Reception History on the New Testament and Antinomianism .................................... 173

Michael Peppard

Law and Liberty: Circumcision Discourse from Galatia to Germany . . . . 193

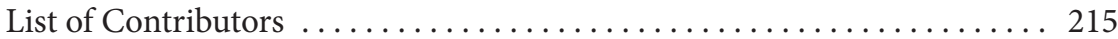

Index of Ancient Sources . . . . . . . . . . . . . . . . . . . . . . . . 217

Index of Modern Authors ............................... 226

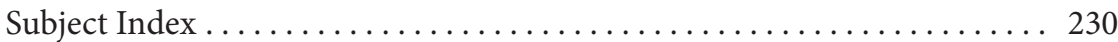

E-offprint of the author with publisher's permission. 


\title{
Weak and Useless? Purity, the Mosaic Law, and Perfection in Hebrews
}

\author{
David M. Moffitt
}

\section{Introduction}

In the opening chapter of the Epistle to the Hebrews, the author approvingly cites LXX Ps 44:8 with reference to the heavenly Son. God says to the Son in Heb 1:9,

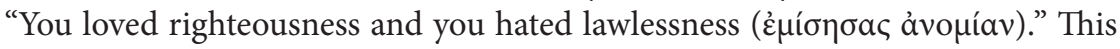
very love of righteousness and hatred of lawlessness is identified as the rationale for God's anointing the Son and thereby elevating him beyond his peers. Despite this claim about hating lawlessness, one aspect of Hebrews sometimes identified as a clear indicator of the text's supersessionist character is the author's presumed disdain for the Mosaic Law's external rituals. The author avers in Heb 9:9-10 that these rituals cannot "perfect the conscience of the worshiper, but deal only with food and drink and various baptisms, regulations for the body imposed until the time comes to set things right" (NRSV). The Law, being "weak and useless" (7:18), was never able to perfect anything (7:19). The author's appeal to Ps 40 in Heb 10 even seems to suggest that God has no desire for external, earthly sacrificial rituals. ${ }^{1}$ Now that Jesus has offered a better sacrifice than anything prescribed by the Law, the Law and its external rituals have been replaced. Jesus' once-for-all sacrifice means the Law and its sacrifices have become outmoded and can be discarded.

Indeed, some have argued that the implications of Hebrews' claims about Jesus' sacrifice so destabilize and subvert the Law's sacrificial logic that in the course of making these claims, the author saws off the very theological branch upon which his argument rests when he maintains that Jesus' death was the ultimate sacrifice. ${ }^{2}$ On the one hand, the author affirms in 9:22 that the aspersion

${ }^{1}$ For example, Wilfried Eisele argues that Christ's full obedience to God's will in Heb 10 renders earthly rituals and offerings useless: "Denn alle Heiligungsversuche unsererseits müßten sinnlose, weil irdische Veranstaltungen bleiben" (Ein unerschütterliches Reich: Die mittelplatonische Umformung des Parusiegedankens im Hebräerbrief, BZNW 116 [Berlin: De Gruyter, 2003], 105). Hugh Montefiore suggests the critique of sacrifice in Heb 10 cannot be limited to particular rituals, but indicates a more general "divine disapproval of the Law itself" ( $A$ Commentary on the Epistle to the Hebrews, HNTC [San Francisco: Harper \& Row, 1964], 168).

${ }^{2}$ A. J.M. Wedderburn, "Sawing off the Branches: Theologizing Dangerously Ad Hebraeos," JTS 56 (2005): 393-414.

E-offprint of the author with publisher's permission. 
of blood is necessary for forgiveness. On the other hand, his interpretation of Ps 40 in Heb 10 appears to obviate the whole notion that God wants sacrifice at all. ${ }^{3}$ "Hebrews," A. J. M. Wedderburn comments, "seems to persist resolutely with cultic terminology even after it has, to all intents and purposes, dealt the cultic way of thought a coup de grâce."4 For Wedderburn, the fundamental contradictions in Hebrews result from the collision of apocalyptic and Platonic worldviews that are constitutive of the somewhat confused thought world of the epistle. The idea that the preexistent Son could become human and then, at the decisive salvific moment of his death, leave his body and the material realm to return to heaven while still being thought to offer his blood in that heavenly realm deconstructs both the author's sacrificial theology and his supposed Platonic foundations.

Such arguments are clearly supersessionist and antinomian, relegating the very logic of the Law with its material concerns and rituals to the dustbin of history. They are also, according to Wedderburn, incoherent. How can Jesus leave the material realm but still have his blood with him? How can the cross be both a historical event and a heavenly/spiritual one? In fact, Wedderburn suggests, the more seriously the author of Hebrews takes his claims that the crucifixion is the heavenly moment of Jesus' high-priestly offering, the more unstable and incoherent his entire theological project becomes.

I have argued elsewhere that this sort of reading of Hebrews is mistaken on several levels. Hebrews does not presuppose a dualism or cosmology that is essentially Platonic. ${ }^{5}$ In my view, the author also does not claim that the atoning sacrifice Jesus offered is reducible to the historical event of the crucifixion. Rather, the author thinks that the atoning sacrifice Jesus offered culminated in the presentation of himself alive in his resurrected humanity when he ascended to the Father and entered the heavenly holy of holies. ${ }^{6}$ I will not rehearse those arguments here. I want instead to examine the assumption that the author rejects the Law and its sacrificial logic because the rituals required by the Law were only effective for earthly, external matters and could not effect internal purification.

Hebrews' claim that the Law only produced limited and external purification is shocking. I am persuaded that Susan Haber is correct when she suggests that such a claim limits the purifying force of the cultic elements of the Mosaic economy to the realm of ritual purification. ${ }^{7}$

${ }^{3}$ Wedderburn, "Sawing off the Branches," esp. 401-4.

${ }^{4}$ Wedderburn, "Sawing off the Branches," 409.

${ }^{5}$ David M. Moffitt, "Serving in the Tabernacle in Heaven: Sacred Space, Jesus's High-Priestly Sacrifice, and Hebrews' Analogical Theology," in Hebrews in Contexts, ed. Gabriella Gelardini and Harold W. Attridge, AJEC 91 (Leiden: Brill, 2016), 259-80.

${ }^{6}$ See, esp., David M. Moffitt, Atonement and the Logic of Resurrection in the Epistle to the Hebrews, NovTSup 141 (Leiden: Brill, 2011).

${ }^{7}$ Susan Haber, "From Priestly Torah to Christ Cultus: The Re-Vision of Covenant and Cult in Hebrews," JSNT 28 (2005): 105-24. For my own detailed engagement with and critique of Haber's essay see, David M. Moffitt, "Wilderness Identity and Pentateuchal Narrative: Distin-

E-offprint of the author with publisher's permission. 
I am also persuaded, however, that Haber, Wedderburn, and others go wrong when they deduce from this polemic that the author must therefore reject ritual purity concerns and even the entire logic of Levitical sacrifice, and replace these with a preformed Christology centered on the death of Jesus as the ultimate saving event. I argue here that the author's close connection between perfection, purity, and one's ability to approach God's presence, especially in the case of Jesus, indicates instead that the very concerns of both moral purity/sin and ritual purity, which is not sin, lie at the center of his soteriological reflection. The author confesses that Jesus, although he is the heavenly Son and is without sin, had nevertheless to be made perfect in his humanity in order to become the great high priest, return to the heavenly realms, and minister there on behalf of his brothers and sisters. Such a concept of perfection, I argue, overlaps significantly with Jewish ritual purity concerns.

Yet if this is correct, then the author's arguments about the Law's limited powers of purification do not support the further inference that he rejects entirely sacrificial ritual and external purification, replacing or superseding them with something wholly other, something inimical to the Levitical rituals - the claim that Jesus' death is the means of inner, moral purification for others. Rather than rejecting the logic of sacrifice and external purification found in the Mosaic Law, the author has instead pushed that logic to what he takes to be its ultimate conclusion - purification that makes one fit to enter fully and permanently into the sacred space of God's heavenly presence. The author of Hebrews, I suggest, speaks of this kind of purification in terms of perfection. Before examining Hebrews directly, however, it will be helpful to consider some of the important work on the concepts of Jewish ritual and moral purity that has been done in the last few decades.

\section{Conceiving Ritual and Moral Purity}

In his book Impurity and Sin in Ancient Judaism, Jonathan Klawans advances the thesis that the biblical conception of purity, as well as the conception found in some expressions of Second Temple Judaism and later Rabbinic Judaism, is best understood as consisting of two parallel purity systems - the ritual and the moral. ${ }^{8}$ Klawans is engaging in an argument whose full scope lies outside the

guishing between Jesus' Inauguration and Maintenance of the New Covenant in Hebrews," in Muted Voices of the New Testament: Readings in the Catholic Epistles and Hebrews, ed. Katherine M. Hockey, Madison N. Pierce, and Francis Watson, LNTS (London: Bloomsbury T\&T Clark, 2017).

${ }^{8}$ Jonathan Klawans, Impurity and Sin in Ancient Judaism (Oxford: Oxford University Press, 2000), esp. 21-32.

E-offprint of the author with publisher's permission. 
purview of this study. Nevertheless, a brief summary of his understanding of these two systems will be useful here.

The biblical ritual purity system has to do with those events and activities delineated in the Bible (see esp. Leviticus 12-15) that render persons or inanimate objects impure, as well as with the particular ritual means by which this impurity can be rectified. Importantly, ritual impurity is only skin deep. That is to say, this kind of purity has nothing to do intrinsically with the purity of the interior self, but only with the purity of one's body.

By the time of the late-Second Temple period, a number of situations and activities were considered to render a person or thing ritually impure. ${ }^{9}$ For example, stepping over a grave, touching a corpse, or even being in the same "tent" as a corpse would render a person ritually impure. Sexual intercourse, menstruation, and the emission of semen also rendered people and objects they come in contact with impure. The birth of a child made a woman ritually impure. Various skin ailments would make a person impure. Moreover, in many cases persons or objects that are in an impure state can further transmit that impurity to those who came into certain kinds of contact with them.

Notably, none of these activities necessarily involved any kind of sin or moral fault. Birthing a child, preparing a corpse for burial, developing a skin disease, menstruating, emitting semen - none of this was deemed to be sin. All of these things, however, created some kind of contaminating force that infected, as it were, people and things and made them impure, usually by way of direct, physical contact. By the same token, touching a corpse, or a person who had a skin disease, or a woman who was menstruating, or a man who had recently ejaculated made one impure, but again, to touch and thereby contract impurity was not to sin.

The solution for these ritual impurities generally involved the passage of time and washings. ${ }^{10}$ Semen emission, for example, made a Jewish man impure. He and those with whom he came into certain kinds of contact could become pure by immersing and waiting until sunset (Lev 15:1-11). The removal of impurities contracted by the birth of a child, or from a skin disease, or from a corpse required more complicated and interesting processes. A woman who bore a male child, for example, was impure for a period of seven days, as with her menstruation, and then for an additional 33 days bringing her time of impurity to a total of 40 days (Lev 12:1-5). At the end of this period she was required to bring a burnt offering and a so-called "sin" offering (Lev 12:6-8). Only then would she be fully purified from the act of giving birth (Lev 12:8). The fact that blood sacrifices formed a component of purification in certain cases such as the birth of a child is a matter to which I return below. The central point for the moment is

${ }^{9}$ For a well-reasoned discussion on the kinds of activities and circumstances that were likely considered to render one ritually impure in the Second Temple period see E. P. Sanders, Judaism: Practice and Belief, 63 BCE-66 CE (London: SCM Press, 1992), $217 \mathrm{ff}$.

${ }^{10}$ See esp. Sanders, Judaism, 72.

E-offprint of the author with publisher's permission. 
that the preceding examples prove that the contraction of ritual impurities was not necessarily a matter of moral transgression/sin.

This is not to say that ritual impurity matters could not cross over into the realm of sin. They could, particularly in cases where certain actions caused one who was ritually impure to transgress a prohibition. One of the primary places where such transgression became possible was the sacred space of the temple. Leviticus 12:4, for example, makes it abundantly clear that a woman who is impure on account of giving birth must not touch any holy thing or come into the sanctuary while in her impure state.

Corpse impurity was also to be kept out of the sacred precincts. The underlying principle seems to be that ritually impure persons were not allowed to draw near to God's presence. ${ }^{11}$ This likely explains the logic behind the curious fact that the high priest was the one person whom Leviticus explicitly says must avoid being contaminated by a corpse (Lev 21:10-11). Indeed, relative to the average person, the rules for priests were also much more stringent in this regard, though they are not bound by the strict prohibition that applies to the high priest (Lev 21:1-3). The rationale for these stricter rules seems to be that because the priests, and the high priest in particular, came closest to the presence of God, they were required to be far more careful about their ritual purity status. ${ }^{12}$ If they were to become impure and then come close to God's presence, they would be guilty of sin.

The preceding discussion implies that the primary point at which ritual impurity became a major concern or crossed over into the realm of sin concerned coming into the sacred space of the sanctuary and thus also drawing near to the presence of the God who dwelt there. God did not allow ritually impure persons to come too near his presence. But why was this? Jacob Milgrom, among others, makes a cogent case that a core concern in matters of ritual impurity was the presence and problem of death. Ritual purity concerns often had to do with the presence or appearance of decay. Loss of blood, semen, the deterioration of the body in the case of skin diseases, and, of course, the human corpse all suggest the diminution of the body's life force and thus the presence of death. God will not tolerate death being brought into his presence. ${ }^{13}$

Yet death cannot be the only factor in play. Hyam Maccoby notes that if death were the only concern at the center of ritual impurity then it is strange that while the loss of vaginal blood makes a woman impure, presumably by loss of life force, bleeding from a wound, something that could actually lead to death, does not. ${ }^{14}$

${ }^{11}$ Sanders (Judaism, 70-72), among several others, makes a compelling case that proximity to God's presence in the temple served as the primary rationale underlying purity concerns.

${ }^{12}$ So Sanders, Judaism, 71-72.

${ }^{13}$ See his discussions of this in, e. g., Jacob Milgrom, Leviticus 1-16: A New Translation with Introduction and Commentary, AB 3 (New York: Doubleday, 1991), 46, 767, 1002-3.

${ }^{14}$ Hyam Maccoby, Ritual and Morality: The Ritual Purity System and Its Place in Judaism (Cambridge: Cambridge University Press, 1999), 31.

E-offprint of the author with publisher's permission. 
Why, moreover, does giving birth make a woman impure? Obviously the process of birth involves the issue of vaginal blood, but if that were all that were going on, it is odd that the woman would be considered impure for several weeks beyond the normal seven days of menstruation impurity. It seems that the birth of the child itself somehow increases the magnitude of the woman's impurity. Maccoby therefore suggests, I think correctly, that the problem is not death alone, but the cycles of mortality in general - sex, birth, decay, and death, functions that relate to and are even definitive of mortality, lie at the center of ritual purity. ${ }^{15}$

The realm of moral impurity, to continue with Klawans' terminology, differs in significant ways from that of ritual impurity. I noted above that Klawans is addressing a much larger argument than can be fully discussed here. Essentially the debate centers around whether or not sin produces a real defiling force as ritual impurity does, or if the language that speaks of sin producing some kind of impurity amounts only to a metaphorical application of ritual impurity language to the abstract realm of moral infraction. Klawans argues, persuasively in my view, that the category of "impurity" should properly be applied to sin because sin, like the ritual matters mentioned above, produces real defilement. Thus, it is appropriate to speak of a system of moral purity, just as it is to speak about one of ritual purity. This system is not, however, identical to that of ritual purity.

Whereas ritual impurity need not be, indeed could not be, ultimately avoided, one was to seek to avoid moral impurity because this kind of impurity resulted from violating a divine prohibition or failing to perform a divine command. The discussion above showed that ritual impurity was only external and involved a great deal of contagion by physical touch. This is not the case for moral impurity. Sinful acts result in moral impurity that defiles the sinner inwardly, but this impurity does not defile other people. Thus, one cannot pass along moral impurity to another person or thing by contact. This is not to say, however, that moral impurity does not convey defilement. Moral impurity conveys defilement to the land of Israel (see esp. Lev 18:24-25), something ritual impurity never does. Furthermore, the defilement caused by some sin seems to transfer an impurity directly to the sacred space of the sanctuary, even from a distance (see, e.g., Lev 20:3 where the abominable sin of an Israelite sacrificing a child to Molech, presumably at one of Molech's temples, nevertheless defiles God's sanctuary). Moral defilement therefore attaches to the sinner in some internal sense, the land, and the sanctuary simply by the commission of the prohibited act. This defilement is not external and not visible to the human eye, but it is nevertheless real and brings real consequences.

In yet another way this kind of defilement differs from that of ritual impurity: neither time nor washing can purge the stain of sin. Moral purification involves repentance, recompense, and the offering of sacrifices. Ultimately, however, the

${ }^{15}$ Maccoby, Ritual and Morality, 49-50, 207; cf. Sanders, Judaism, 217.

E-offprint of the author with publisher's permission. 
defilement of the land and temple that results from moral impurity can build to the point that the land reacts by "vomiting out" the people who dwell upon it (e.g., Lev 18:26-30), and the presence of God can depart from the sanctuary. ${ }^{16}$

Thus, there are key differences between these two systems, but there are also key parallels. Klawans summarizes the situation well when he writes,

[W] e ought to understand that with both kinds of impurity, we are dealing with perceived effects that result from actual physical processes. In the case of ritual impurity, a real, physical process or event (e.g., death, menstruation) has a perceived effect: impermanent contagion that affects people and certain objects within their reach. In the case of moral impurity, a real, physical process or event (e. g., child sacrifice or adultery) has a different perceived effect: a noncontagious defilement that affects persons, the land, and the sanctuary. ${ }^{17}$

In short, both systems of purity have to do with real impurities that convey to real objects, even if the ways in which these impurities convey and the things to which they are conveyed differ markedly from each other.

There is, however, a curious fact about these two systems of purity that Klawans says little about: while many cases of ritual impurity require no sacrifice for purification, some cases do. Also curious is the fact that the sacrifices for purification in both the ritual and moral systems are the same - the so-called "sin" offerings. That is to say, when a moral infraction needed to be rectified, the guilty party had to offer a "sin" offering. This sacrifice was essential for atonement (see, e. g. Lev 4:27-35). In certain cases of ritual impurity, however, the person in need of purification also had to offer a "sin" offering that also effected atonement for them (see esp. Lev 12:6-8 where the woman who has given birth has to offer a "sin" offering by which the priest makes atonement for her).

Jacob Milgrom's theory about ritual impurity mentioned above accounts for this strange situation by positing that, like moral impurity, some ritual impurities also convey a stain to the sanctuary. While not universally accepted, ${ }^{18}$ this theory makes a great deal of sense at this point. Milgrom argues that both severe ritual impurities (such as giving birth and corpse impurity) and sins/moral impurity defile the sanctuary and its altars even from a distance. The more serious impurities penetrate more deeply into the sacred precincts than the more minor ones. This would explain the need for blood sacrifices in cases of sin and of certain ritual impurities such as birth. Blood, Milgrom argues, has the power to cleanse or purify the altars and the sacred precincts from the impurities that cling to them as a result of moral and ritual impurities. ${ }^{19}$

16 This last point is made with particular force in Jacob Milgrom, "Israel's Sanctuary: The Priestly 'Picture of Dorian Gray,"' RB 83 (1976): 390-99.

${ }^{17}$ Klawans, Impurity and Sin, 34.

${ }^{18} \mathrm{See}$, for example, the multiple criticisms of Milgrom's theory in Maccoby, Ritual and Morality.

${ }^{19}$ See esp. Milgrom, Leviticus 1-16, 254-58, 711-12.

E-offprint of the author with publisher's permission. 
As evidence Milgrom points to cases where sacrificial blood is applied to an altar or other part of the sanctuary and the object of the verb for atonement, kipper, is the sanctuary or the altar to which the blood is applied. In Lev 16:15-20, for example, the holy place, the tent of meeting and the altars are "atoned for" by way of blood application. The atoning action, in other words, is that of purification. The detergent or agent that effects that purification is blood.

Importantly, Lev 16:16 identifies both the uncleanness (i. e., ritual impurity) and the sins of the people as the sources of defilement that make the annual purification necessary. The clear implication of this is that both the peoples' ritual and moral impurities have defiled the sacred precincts, which are consequently in need of cleaning/purification. This regular cleansing was essential to the covenant relationship. If this ongoing maintenance were not performed, the level of impurity would build to the point that God's presence would depart (see, e.g., Ezek 5:11). Blood application in this sacred space was a necessary means for effecting the sanctuary's purification.

Where Milgrom's theory seems weakest, however, concerns the relationship between the purification of the altars and sacred spaces, and that of the people for whom sacrifices are being offered. Milgrom argues that blood purifies objects by way of direct, physical application. Since blood is not applied to the person bringing the sacrifice, Milgrom reasons that sacrifice does not play a role in purifying the offerer. Sacrifice is necessary only to purify the altars contaminated by the peoples' sins and ritual impurities. The offerer, in the case of sin, is purified from the defilement of sin by experiencing guilt and repenting. ${ }^{20}$ In ritual matters, the offerer is purified by time and washings.

Roy Gane has levelled a trenchant critique against Milgrom at just this point. ${ }^{21}$ Gane points to texts that do in fact link the offering of sacrifice with the purification of the offerer. In Lev 12:7, for example, the woman who gave birth is finally rendered pure from $(\mathrm{min})$ her ritual impurity by means of the sacrifices she offers. Similarly, in Num 8:12, 21 the Levites are purified by their sacrifices. Sacrifice, in other words, does seem to remove impurity from the offerer. This evidence suggests that Milgrom's theory is only half right. Milgrom's theory of the conveyance of impurities to the holy places from a distance is correct, but suffers from being unidirectional. Just as one need not be in contact with the sacred spaces to convey impurity to them, so also, Gane argues, the purity effected by blood application to the altars can have the effect of purifying the offerers too. Blood, that is, need not be applied directly to the people in order for the purity it effects on the sacred appurtenances to be reciprocally conveyed to them.

${ }^{20}$ Milgrom, Leviticus 1-16, 254-56, 1056-58.

${ }^{21}$ Roy Gane, Cult and Character: Purification Offerings, Day of Atonement, and Theodicy (Winona Lake, IN: Eisenbrauns, 2005), esp. 106-43.

E-offprint of the author with publisher's permission. 
One more conversation partner is worthy of mention here. In his book Sin, Impurity, Sacrifice, Atonement: The Priestly Conception, Jay Sklar notes that while Klawans rightly highlights distinctions between the systems of ritual and moral impurity, the fact that the same sacrifices (esp. the "sin" offering) are required in the case of some ritual impurities as are required for moral impurities suggests that at this point the two systems converge. ${ }^{22}$ This becomes even clearer when one considers the end results of both kinds of impurities. That is to say, both ritual impurity and moral impurity create defilement that puts the people in danger with respect to God, and threaten God's willingness to remain present in the sanctuary.

Sklar argues further that the term kipper, which is used to resolve both kinds of impurity, should not be pressed too hard to mean only purification in matters of ritual purity and only ransom in matters of moral purity. In sacrificial contexts, the means for effecting both ransom and ritual purification is the application of sacrificial blood, especially the blood of the "sin" offering. Thus, Sklar suggests, sacrificial atonement cannot be reduced to either ransom or purification, but should be understood as including both ransoming and purifying effects. ${ }^{23}$

This cursory discussion of the ritual and moral purity systems depicted in the Hebrew Bible can now be summarized. Ritual purity is primarily a matter of one's external condition. This kind of defilement is contagious and usually spread by contact. At its core, ritual impurity appears to be about matters of mortality. Further, ritual impurity is a major obstacle when one tries to come close to God's presence. God does not permit ritually impure persons to come close to his presence. To bring impure mortality into God's sacred space is to be guilty of sin. The need for people to be in a ritually pure state therefore appears to be primarily about rendering mortal humanity fit to draw near to God's presence.

Moral purity has to do with obeying God's commands. The violation of divine directives results in moral defilement. A person's moral impurity is not external and is not contagious. Nevertheless, while ritual and moral purity are distinct, both problematize the relationship between God and his people. Ritual impurity prevents the people from approaching God. Moral impurity threatens their ability to dwell in the land, which is defiled by sin, and threatens them with God's punitive wrath. Both kinds of impurity further stand in the way of God and his people dwelling together because both convey defilement to the sanctuary. The sanctuary needs regular purification if God's presence is to remain there.

It further appears to be the case that sacrificial atonement in the fullest sense that is, the state that results from solving the problems of moral and ritual impu-

${ }^{22}$ Jay Sklar, Sin, Impurity, Sacrifice, Atonement: The Priestly Conceptions, HBM 2 (Sheffield: Sheffield Phoenix, 2005), 144-50, esp. 149.

${ }^{23}$ For a condensed version of his argument see Jay Sklar, "Sin and Impurity: Atoned or Purified? Yes!" in Perspectives on Purity and Purification in the Bible, ed. Naphatali S. Meshel, et al, LHB/OTS 474 (London: T\&T Clark, 2008), 18-31.

E-offprint of the author with publisher's permission. 
rity such that God and humanity can dwell together - requires the removal of the threat of God's wrath by way of redemption or ransom and the purification of the people, the land, and the sanctuary. Full atonement, in other words, is effected when the defilement from both moral and ritual impurities is purged.

But what does any of this have to do with Hebrews? I demonstrate next that the meaning of perfection language in Hebrews overlaps at points with both of these concepts of purity. To be more specific, the author at times uses perfection language to mean the complete and enduring rectification of the impurities that separate God and humanity. If this is right, then the fact that Jesus needed to be perfected suggests that the writer has purity concerns in view. Yet, the fact that Jesus, who was without $\sin /$ moral impurity, nevertheless needed to be perfected implies that, even though he is the heavenly Son, his mortal humanity required purification before he could approach the Father in the sacred heavenly space and serve there as the high priest for his people. This, however, implies that the writer has not dismissed the importance of the kinds of external matters so central to the ritual purity system detailed in the Law.

\section{Perfection as Purity in Hebrews}

That the author of Hebrews thinks in terms of moral purity is abundantly clear

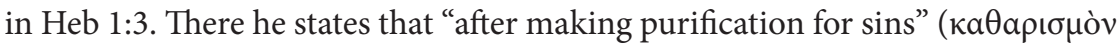

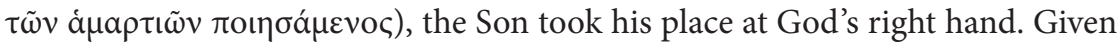
Hebrews' portrayal of Jesus as the high priest who enters the heavenly holy of holies, the collocation of the terms "purification" and "sin" probably signals an allusion to the statement in OG Lev 16:30 that the high priest's atoning work on

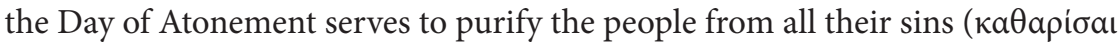

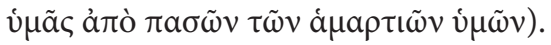

Equally clearly the writer employs a concept similar to that described above as ritual purity. As was noted, one of the oddities in Hebrews is the author's claim that the sacrifices prescribed in the Law did not effect moral purification, but only brought about a limited purification of the body. Hebrews, as Haber has stated, appears to have reduced purification in the Law to ritual purification. But does this mean that the author goes on to reject the logic of ritual purification and its concern for external and bodily things? The author's use of perfection language indicates that this is not the case.

The close link between perfection and immortal life made by the author in Heb 7 is, as I have argued elsewhere, one among many clues that the author assumes Jesus' bodily resurrection in his argument. ${ }^{24}$ The logic of the argument in this chapter works by way of a contrast between the Law, which links priestly legiti-

${ }^{24}$ Esp. Moffitt, Atonement and the Logic of Resurrection, 194-208.

E-offprint of the author with publisher's permission. 
macy and authority with Levitical tribal lineage, and the power of Jesus' enduring resurrection life. The Law's linkage of tribal lineage/genealogy and legitimate priestly succession is bound up with the reality of death. The writer stresses this point explicitly in 7:8 and 7:23, and implicitly gestures towards it when he argues that the kind of life that Melchizedek and Jesus have legitimates their priestly status in spite of their genealogies (cf. 7:3, 16, 24-25). The point seems to be that Jesus, as a human being, became the great high priest he is confessed to be when, in his humanity, he was raised from the dead never to die again.

As the author wraps up the argument of ch. 7 and transitions to another point, he restates this critical contrast between the Law and Jesus' enduring life in different terms when he says, "The Law appoints men as high priests who have weaknesses, but the word of the oath, which came after the Law, appoints as high priest a Son who has been made perfect forever" (7:28). Given the contrast in the preceding argumentation of Heb 7, one can gloss 7:28 as follows: The Law appoints as high priests men who are subject to death, while the oath of Ps 110:4 appoints Jesus, the Son, who is not subject to death and thus lives forever. The Law's emphasis on genealogy as much as proves that the Levitical priests could not escape death, because the very logic of genealogy presupposes the reality of death. This is a major element of their and the Law's "weakness." By way of contrast, the perfection of the Son means he does not share this weakness. He now lives in such a way that he will never again be subject to death.

By linking the Law with death and Jesus with life the author makes a move analogous to that of Paul as he thinks about the Law. It appears that both Paul and Hebrews agree that the Law was unable to bring life to God's people. Paul goes beyond Hebrews when he argues that the Law, though good, became a tool of death. Like Paul, however, Hebrews seems to be working with an apocalyptic dualism that views the created realm as somehow separated from God's presence because it is tainted with sin, death and corruption. The Law is inextricably connected to the pole of this dualism that is subjected to death and the one who holds the power of death - the devil (cf. Heb 2:14).

If this is basically right, then when the author of Hebrews argues that the Law never made anything perfect, he is claiming that the Law was never able permanently to move God's people from their present condition into the fullness of God's presence. The Law, to put the point differently, never fully solved or dealt with the problem of death. In fact, the problem of death is in some sense hardwired into the very logic of the Law, particularly in the ritual purity codes and the genealogical stipulations regarding priestly service. This further means that the Law never purified people to the point that their subjection to mortality was no longer a problem that prevented them from entering the fullness of God's presence. This, I suggest, is what the author means when he says that the Law's regulations regarding genealogy and priesthood are "weak and useless." What the Law in its weakness could not do, however, the author of Hebrews argues

E-offprint of the author with publisher's permission. 
the Son has accomplished by rising again and ascending into the heavens as the great high priest.

I do not intend to imply here that the meaning of perfection in Hebrews is exhausted by or reducible to the idea of enduring life. I am, however, suggesting that these nuances in the author's argument indicate that ritual purity concerns lie close to hand in some of his uses of perfection language. Indeed, the presence of a notion of purity is already hinted at in his contrast in 7:19 between the Law's inability to perfect anything and the better hope in Jesus that enables his followers to approach God. As noted above, the ritual purity codes in Leviticus are designed to enable people to approach God by rendering their mortality fit to draw near to his presence.

Hebrews 9:9 and 9:14 provide substantive confirmation that perfection and purity overlap for the author. In these verses the terms perfection and purification are used interchangeably. In 9:9 the author claims that the gifts and sacrifices offered under the Law could not perfect the conscience of the worshippers. In 9:14, by way of contrast, he points out that the blood of Christ purifies the conscience. This is solid evidence that perfection and purity can be used synonymously in Hebrews. Equally clearly, though, these statements imply a concept of moral purity (as in 1:3), not ritual purity.

Yet the situation is different in the case of Jesus himself. The author characterizes Jesus' life as being "without sin" (4:15). In the midst of his testing, Jesus was sinless. Jesus, in other words, was morally pure. He had no need to offer any sacrifice for himself in order to deal with his own $\sin (7: 27)$. Nevertheless, the author plainly states throughout the epistle that Jesus was perfected, implying a need for this perfecting $(2: 10 ; 5: 9 ; 7: 28)$. What could it mean that Jesus, the preexistent Son of God, had to be made perfect?

Many arguments have been offered in the past to explain this language. ${ }^{25} \mathrm{Giv}$ en the linkage of perfection and purity in Hebrews noted above, I suggest that

${ }^{25}$ E. g., Paul J. Du Plessis argues that perfection language in Hebrews primarily relates to Jesus' priestly consecration, though not to the exclusion of his subjective, existential development as a human being (TE $L E I O \Sigma$ : The Idea of Perfection in the New Testament [Kampen: J.H. Kok, 1959], esp. 212-17, 243). David Peterson pushes back on this and other ideas by suggesting instead that Jesus' incarnate suffering, saving death and exaltation should be viewed as a process that makes Jesus fit for the vocation of being a merciful high priest who can fully save his people (Hebrews and Perfection: An Examination of the Concept of Perfection in the "Epistle to the Hebrews," SNTSM 47 [Cambridge: Cambridge University Press, 1982], esp. 49, 67, 73, 103). David A. DeSilva links Jesus' perfection with his "arrival at his heavenly destiny" (Perseverance in Gratitude: A Socio-Rhetorical Commentary on the Epistle "to the Hebrews" [Grand Rapids: Eerdmans, 2000], see 197-99, here 199). Kevin B. McCruden, on the basis of the documentary papyri, has more recently argued that perfection language could carry the notion of public, definitive/official attestation of a transaction (Solidarity Perfected: Beneficent Christology in the Epistle to the Hebrews, BZNW 159 [Berlin: DeGruyter, 2008], 26-37). In the context of Hebrews this implies that perfection language is mainly language intended to comment in a public and definitive way on the beneficent, personal character of Jesus' high-priestly sacrifice $(69,117-21,139)$.

E-offprint of the author with publisher's permission. 
perfection language as applied to Jesus also verges into the realm of purity. ${ }^{26}$ Yet, in the case of Jesus, the Son of God, the purity in play is not in the moral realm but in the realm of ritual. If, as I have argued, Jesus' perfection has to do with his resurrection to immortal humanity, ${ }^{27}$ then the concept of purity that does apply to Jesus would have to do with the purity of his body. Although he was the Son, in his humanity he was fully mortal and, as such, was subject to ritual impurity. Prior to his resurrection, Jesus, the Son of God, was subject to death and did in fact die as a human being.

To put the point differently, the ultimate problem of mortality and the way in which death hindered humanity from fully entering God's presence applied to Jesus' imperfect/mortal humanity. This logic looks remarkably similar to the logic of ritual purification. Thus when, after his death, Jesus was perfected, the point seems to be that he was made fully, ritually pure. Jesus' humanity was, in other words, given the better resurrection promised in Heb 11:35. At this moment of perfection, Jesus' humanity was no longer mortal, no longer subject to death. Jesus is, therefore, never again subject to the problem of ritual impurity. Because of this perfection, that is to say, because his humanity has been fully and irrevocably purified, he was able to do what no other high priest has done - ascend into the sacred space of the heavenly sanctuary, draw close to the fullness of God's presence, and importantly, remain there.

\section{Hebrews, the Law, and Supersessionism}

If the preceding conclusions are properly tapping into the author's logic, then they hold important implications for the larger questions of supersessionism in Hebrews and the author's apparently disparaging language about the Law. I have already suggested that for the author of Hebrews the Law's limitations follow from the fact that the Law is in some sense itself subject to death and corruption. Hebrews seems to work with an understanding that the Law's sphere of authority and legitimacy is circumscribed by the fact that it is bound up with an age that will pass away once the world/age to come arrives.

This is a significant point, because it implies that the author's comments about the Law's limitations with respect to perfection are not a dismissal of the legitimacy and authority of the Law within its proper sphere. In fact, in one of the more overlooked verses in modern Hebrews commentary the writer notes that the Law's authority prevents Jesus from being a priest on earth. Hebrews 8:4 reads

${ }^{26}$ This has been noted at various times. William G. Johnsson, for example, argues that from a cultic perspective perfection language in Hebrews has partly to do with allowing access to the heavenly cult (Defilement and Purgation in the Book of Hebrews [Ph.D. diss., Vanderbilt University, 1973], 260-63).

${ }^{27}$ Moffitt, Atonement and the Logic of Resurrection, 198-214.

E-offprint of the author with publisher's permission. 
that "If he [i. e., Jesus] were on earth, he would not even be a priest because there exist those who offer the gifts in accordance with the Law." The writer takes seriously the fact that Jesus has now passed through the heavens and entered God's presence. This is one of the reasons that Hebrews so consistently locates Jesus' priestly work in the heavens. On earth, the Law forbids him from legitimately holding priestly office and thus serving in priestly ministries (Heb 8:4).

Such a claim indicates that the author has not simply dismissed the authority of the Law. In the heavenly sphere and in the coming age, the Law's limitations, particularly in the realm of ritual purity, do not apply. In a way not unlike Paul in Gal 3, this argument relies on Jewish apocalyptic periodization to bracket the Law by locating it within a particular period/age, a circumscribed place and time that precedes the eternal age. At least some of the Law's regulations will, therefore, go the way of the rest of the corruptible realm with which it is so closely bound (cf. Heb $1: 13-14 ; 8: 13 ; 12: 27$ ). When the earthly realm is finally shaken for the last time, such that only the unshakable realities remain, the Law will be "metathesized" or changed (cf. Heb 7:11-12, 18-19; 8:13).

But the language of "supersessionism" does not accurately describe this kind of logic. The idea that perfection entails the purified and enduring life of the resurrection and the eternal age to come would obviate the Law's ritual purity codes in some notable ways. What contamination by death and corruption is present or even possible for one who lives in such an immortal state? When there is no possibility of impurity from mortality, the need for rituals of bodily purification disappears.

\section{Conclusion}

Within the Mosaic economy, both moral and ritual impurity prevented full communion and fellowship between God and his people. These problems were mitigated by way of sacrifice and other rituals. But, the author of Hebrews reasons, how much better would be the situation in which moral defilement/sin was fully erased never to accrue again, and in which ritual impurity could never even be contracted? This situation is at points called "perfection" in Hebrews. Sacrifices are good in their time and place. God was pleased with the sprinkled blood that Abel offered him (Heb 12:24). So also, God is pleased with the sacrifice that the Son offered him. But how much better would the situation be in which sacrifices for forgiveness and purification were no longer necessary because the problems they solve are no longer problems at all? This, I suggest, is the logic of Hebrews' argument. The ritual elements of the Law are surely relativized, but that does not mean that they are somehow bad, inherently negative, or that Hebrews does not apply the logic of such sacrifices to Jesus. The Mosaic rituals are limited, but nevertheless good. The point for the author of Hebrews seems to be that once

E-offprint of the author with publisher's permission. 
one has been perfected and has been able to enter fully into the fullness of God's presence, the need for the Law's rituals of purification and forgiveness disappears.

In sum, Jesus was the sinless Son of God but nevertheless was bound by the limitation of the Law when on earth and had to be perfected in his humanity before he could return to the heavenly realms. Therefore, the links between perfection, purity, and resurrection in Hebrews suggest that the concerns that lie at the center of ritual purity as detailed in the Law are foundational for, not in opposition to, the Christology and soteriology of Hebrews. There is here a polemic against viewing the Law in absolute or eternal terms, but not one which dismisses or denigrates the Law. As with the angels, Moses, Aaron, the priesthood, the Law is good and revelatory for the author of Hebrews, but neither the Law nor these other figures opened the way for God's people to enter the fullness of the inheritance the writer of Hebrews thinks they were ultimately promised. This is a central aspect of what the author means when he highlights Jesus' perfection and the ways in which what he offers is better than what came before. 